Tropical Journal of Pharmaceutical Research September 2020; 19 (9): 1851-1856

ISSN: $1596-5996$ (print); 1596-9827 (electronic)

(C) Pharmacotherapy Group, Faculty of Pharmacy, University of Benin, Benin City, 300001 Nigeria.

Original Research Article

http://dx.doi.org/10.4314/tjpr.v19i9.8

\title{
Icariin induces autophagy and apoptosis of chondrocytes by inhibiting NF-KB signaling pathway
}

\author{
Jun Xiong, Hui Zou, Yi Yu* \\ The Central Hospital of Wuhan, Tongji Medical College, Huazhong University of Science and Technology, Wuhan 430014, PR \\ China \\ *For correspondence: Email: sp107e@163.com
}

Sent for review: 23 May 2020

Revised accepted: 25 August 2020

\begin{abstract}
Purpose: To investigate the effect of icariin on autophagy and apoptosis of chondrocytes, and the associated mechanisms.

Methods: The chondrocytes were randomly divided into control (PBS intervention), TNF- $\alpha$ intervention, icarin $+T N F-\alpha$, and NF-KB inhibition +TNF- $\alpha$, with 8 strains in each group. The levels of IL-1, IL-6 and IL12 were assayed by ELISA. The mRNA and protein expressions of ATG5, ATG7, Bax and Bcl-2 cells were determined by polymerase chain reaction (PCR) and Western blotting, while protein expressions of $p-p 65$ and IkBa were assayed using Western blotting.

Results: In the cartilage tissue of rats in the icariin +TNF- $\alpha$ group and NF-KB inhibition +TNF- $\alpha$ group, IL-1, IL-6 and IL-12 levels were significantly lower than those in TNF- $\alpha$ treatment group $(p<0.05)$. The AATG5 mRNA and protein in cartilage tissues of rats in icariin +TNF- $\alpha$ and NF-KB inhibition +TNF- $\alpha$ groups were significantly higher than those in TNF- $\alpha$ group. Bax mRNA and protein in cartilage tissues of icariin +TNF- $\alpha$ and NF-KB inhibition +TNF- $\alpha$ groups were downregulated, relative to TNF- $\alpha$ group; on the other hand, Bcl-2 mRNA and protein were significantly higher than those of TNF- $\alpha$ group $(p<0.05)$. In the cartilage tissues of Icarin $+T N F-\alpha, N F-K B$ inhibition $+T N F-\alpha$ groups, P-p65 protein was significantly lower than that of TNF- $\alpha(p<0.05)$.

Conclusion: TNF- $\alpha$ enhances the production of a large number of inflammatory factors by cartilage cells, inhibits autophagy of cartilage cells, and promotes cell apoptosis through regulation of NF-KB signaling pathway.
\end{abstract}

Keywords: Icariin, NF-KB signaling pathway, TNF- $\alpha$, Inflammatory response, Chondrocytes, Autophagy, Apoptosis

\begin{abstract}
This is an Open Access article that uses a fund-ing model which does not charge readers or their institutions for access and distributed under the terms of the Creative Commons Attribution License (http://creativecommons.org/licenses/by/4.0) and the Budapest Open Access Initiative (http://www.budapestopenaccessinitiative.org/read), which permit unrestricted use, distribution, and reproduction in any medium, provided the original work is properly credited.

Tropical Journal of Pharmaceutical Research is indexed by Science Citation Index (SciSearch), Scopus, International Pharmaceutical Abstract, Chemical Abstracts, Embase, Index Copernicus, EBSCO, African Index Medicus, JournalSeek, Journal Citation Reports/Science Edition, Directory of Open Access Journals (DOAJ), African Journal Online, Bioline International, Open-J-Gate and Pharmacy Abstracts
\end{abstract}

\section{INTRODUCTION}

Osteoarthritis is a chronic degenerative disease which involves the cartilage, subchondral bone and synovium. The main clinical manifestations of osteoarthritis are joint swelling and pain, as well as joint deformity, stiffness and dysfunction.
The disease is more common in the elderly, with higher incidence and higher disability in women than in men, and it seriously affects the physical and mental health of patients [1].

Currently, clinical treatment of osteoarthritis focuses on relieving pain, delaying progression 
of the disease, restoring joint function through reconstruction, and improving patients' quality of life. Previous studies have suggested that the pathogenesis of osteoarthritis is associated with joint destruction caused by simple cartilage degeneration. However, in-depth studies have revealed that inflammatory response plays a very important role in the pathogenesis of osteoarthritis [2]. In particular, TNF- $\alpha$ is one of the important inflammatory factors that cause cartilage destruction in osteoarthritis. Studies have shown that TNF- $\alpha$ is distributed in different levels in articular cartilage, subchondral bone and synovium. It promotes the release of fibroblast adhesion molecules and binds to activated vascular endothelial cell adhesion molecules, so that white blood cells in the blood are concentrated in the articular cavity [3]. Chondrocytes are one of the important sources of inflammatory reactions, and they are involved in the synthesis and transformation of extracellular matrix during autophagy and apoptosis [4].

Herba epimedii is a traditional Chinese medicinal plant from which is extracted herba epimedin, a bioactive compound with a hormone-like effect which enhances the proliferation and osteogenic differentiation of bone marrow stem cells [5]. The purpose of this study was to determine the effect of icariin on TNF-a-mediated inflammatory response, as well as its effect on autophagy and apoptosis of chondrocytes in a rat model of osteoarthritis.

\section{EXPERIMENTAL}

\section{Reagents and equipment}

Icariin and chloral hydrate were purchased from Sigma. Trypsin and PBD buffer were bought from Hyclone Company, USA. Fetal bovine serum was product of Gibco, USA, while PVDF membrane was obtained from MILLIPORE Inc., USA. Trizol was purchased from Invitrogen, USA. Assay kits for IL-1, IL-6 and IL-12 ELISA were purchased from Wuhan Bainlai Biotechnology Co. Ltd. Rabbit anti-rat primary antibodies for ATG5, ATG7, Bax, Bcl-2, p-p65 and IKBa were purchased from Santa Cruz.

This research was approved by the Animal Ethical Committee of Wuhan Central Hospital Affiliated to Tongji Medical College of Huazhong University of Science and Technology, Wuhan 430014, PR China, according to Principles of Laboratory Animal Care, (approval number was 20198631) [6].
Super clean workbench was bought from Suzhou Jingtai Co. Ltd, while $\mathrm{CO}_{2}$ thermostatic incubator was purchased from Shanghai lishen Scientific Instrument Co. Ltd. Centrifuge was product of Hunan Xiangyi Laboratory Instrument Co. Ltd. Inverted microscope was purchased from Olympus in Japan. Swim meter was bought from Bio-Rad Company, US. Automatic Biochemical analyzer was purchased from Shanghai Technology Co. Ltd. Flow cytometer was product of Beckman. Fluorescence quantitative PCR instrument was purchased from Real-Time System.

\section{Animals and culture of chondrocytes}

Twenty-five healthy SPF rats weighing $180-220$ g, were obtained from the Animal Experiment Center of Tongji Hospital of Huazhong University of Science and Technology. Under chloral hydrate anesthesia, cartilage tissues were taken from the knee joints of rats, and digested with $0.25 \%$ trypsin. Following centrifugation, the chondrocytes were placed in DMEM/F12 medium containing $10 \%$ fetal bovine serum, and inoculated in a culture bottle at a concentration of $1 \times 10^{6} / \mathrm{mL}$, followed by culturing in an incubator at $37{ }^{\circ} \mathrm{C}$ and $5 \% \mathrm{CO}_{2}$. Chondrocytes at logarithmic growth were divided into control group (PBS intervention), TNF- $\alpha$ intervention group, icariin +TNF- $\alpha$ group, and NF-kB inhibition $+\mathrm{TNF}-\alpha$ group, with 8 strains in each group.

\section{Various assay methods used}

Enzyme linked immunosorbent assay (ELISA) was used to determine the levels of IL- 1 , IL-6 and IL-12 in rat cartilage cells. The expression of ATG5 and ATG7 mRNA in rat cartilage tissue was determined using PCR. Total RNA of rat cartilage tissue in each group was extracted with Trizol method. Then, $2 \mu \mathrm{L}$ RNA solution was subjected to $1 \%$ agarose gel electrophoresis in order to determine the purity and integrity of the RNA. Subsequently, reverse transcription was carried out to convert each RNA to cDNA.

Reverse transcription and PCR was used at 42 ${ }^{\circ} \mathrm{C}$ for $50 \mathrm{~min}$, and heated at $95{ }^{\circ} \mathrm{C}$ for $5 \mathrm{~min}$ in order to inactivate the reverse transcriptase. After the reaction, the cDNA products were kept in the refrigerator at $-20{ }^{\circ} \mathrm{C}$ prior to use. The $\mathrm{Ct}$ value of a target gene was obtained, and the relative quantitative analysis of the gene data was conducted using the $2 \Delta^{\Delta}{ }_{C t}$ formula, with GAPDH as the internal reference gene.

The protein expressions of ATG5 and ATG7 in rat cartilage were assayed with Western blotting. Chondrocytes at logarithmic growth in each 
group were collected, and total protein was extracted using protein quantification kit. Equal amounts of protein were separated on SDSpolyacrylamide gel electrophoresis, and then transferred to PVDF membrane. The membrane was blocked by incubation with $5 \%$ non-fat milk at room temperature for $2 \mathrm{~h}$, followed by incubation of the membrane with primary antibodies for ATG5 (1: 5000 dilution) and ATG7 (1: 10000 dilution) overnight in a refrigerator at 4 ${ }^{\circ} \mathrm{C}$. Then, the PVDF membrane bound to primary antibodies was washed with TTBS, and incubated with horse radish peroxidaseconjugated secondary antibody at room temperature for $1-2 \mathrm{~h}$. The bands were analyzed using enhanced chemiluminescence.

The mRNA expressions of $\mathrm{Bax}$ and $\mathrm{Bcl}-2$ in rat cartilage were determined using PCR, while the protein expressions of Bax, Bcl-2, p-p65, ІкBa were determined with Western blotting, using the same procedure described above.

\section{Statistical analysis}

Measurement data are expressed as mean \pm standard deviation (SD). Statistical analysis was done with SPSS20.0 software package. Independent sample $t$-test was used to compare means between two groups, while analysis of variance (ANOVA) was used for multiple group comparisons. Values of $p<0.05$ were regarded as indicative of statistically significant differences.

\section{RESULTS \\ Inflammatory factors in cartilage tissue of rats}

The levels of IL-1, IL-6 and IL-12 in the cartilage tissue of rats in the TNF-a treatment group were significantly higher than those in the control group $(p<0.05)$, while IL-1, IL-6 and IL-12 levels in cartilage tissue of rats in the icariin +TNF- $\alpha$ group and NF-KB inhibition +TNF- $\alpha$ group were significantly lower than those in the TNF-a treatment group $(p<0.05)$. These results are shown in Table 1.

\section{Effect of icariin on TNF- $\alpha-$ mediated chondrocyte autophagy}

The mRNA and protein expressions of ATG5 and ATG7 in the cartilage tissue of rats in the TNF- $\alpha$ intervention group were significantly lower than the corresponding levels in the control group $(p<$ 0.05 ), but they were significantly higher in the cartilage tissue of rats in the icariin +TNF- $\alpha$ group and NF-KB inhibition +TNF- $\alpha$ group than in the TNF- $\alpha$ group $(p<0.05)$. These results are shown in Figure 1 and Table 2.

Table 1: Levels of inflammatory factors in cartilage tissue of rats in each group (mean $\pm S D, n=8$ )

\begin{tabular}{lccc}
\hline Group & $\begin{array}{c}\mathrm{IL}-1 \\
(\mathrm{pg} / \mathrm{mL})\end{array}$ & $\begin{array}{c}\mathrm{IL}-6 \\
(\mathrm{pg} / \mathrm{mL})\end{array}$ & $\begin{array}{c}\mathrm{IL}-12 \\
(\mathrm{pg} / \mathrm{mL})\end{array}$ \\
\hline \multirow{2}{*}{ Control } & $145.26 \pm$ & $65.24 \pm$ & $50.10 \pm$ \\
& 10.33 & 5.33 & 5.98 \\
TNF- $\alpha$ & $482.16 \pm$ & $210.74 \pm$ & $154.26 \pm$ \\
& $17.65^{\star}$ & $15.20^{*}$ & $12.36^{*}$ \\
& & & \\
$\mathrm{I}+\mathrm{T}$ & $253.44 \pm$ & $126.02 \pm$ & $103.68 \pm$ \\
& $12.67^{\#}$ & $10.78^{\#}$ & $10.20^{\#}$ \\
$\mathrm{NF}+\mathrm{T}$ & $302.16 \pm$ & $148.56 \pm$ & $120.74 \pm$ \\
& $13.58^{\#}$ & $11.22^{\#}$ & $11.55^{\#}$ \\
\hline
\end{tabular}

${ }^{*} P<0.05$, compared with the control group; ${ }^{\#} p<0.05$, compared with TNF- $\alpha$ group; I + T, Icariin +TNF- $\alpha$; NF $+\mathrm{T}, \mathrm{NF}-\mathrm{kB}$ inhibition +TNF- $\alpha$

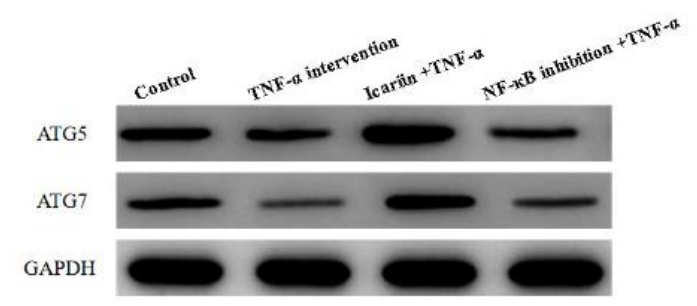

Figure 1: Effect of icariin on protein expressions of ATG5 and ATG7 in TNF- $\alpha$-treated chondrocytes

Table 2: Effect of icariin on protein expressions of ATG5 and ATG7 in TNF-a-treated chondrocytes (mean $\pm \mathrm{SD}, \mathrm{n}=8$ )

\begin{tabular}{lcccc}
\hline \multirow{2}{*}{ Group } & \multicolumn{2}{c}{ ATG5 } & \multicolumn{2}{c}{ ATG7 } \\
\cline { 2 - 5 } & mRNA & Protein & mRNA & Protein \\
\hline \multirow{2}{*}{ Control } & $1.25 \pm$ & $0.42 \pm$ & $1.05 \pm$ & $0.32 \pm$ \\
& 0.13 & 0.03 & 0.06 & 0.05 \\
TNF-a & $0.67 \pm$ & $0.30 \pm$ & $0.85 \pm$ & $0.20 \pm$ \\
& $0.08^{*}$ & $0.04^{*}$ & $0.07^{*}$ & $0.04^{*}$ \\
$\mathrm{I}+\mathrm{T}$ & $5.72 \pm$ & $0.68 \pm$ & $3.88 \pm$ & $0.58 \pm$ \\
& $1.78^{\#}$ & $0.08^{\#}$ & $1.06^{\#}$ & $0.06^{\#}$ \\
$\mathrm{NF}+\mathrm{T}$ & $3.16 \pm$ & $0.40 \pm$ & $2.08 \pm$ & $0.38 \pm$ \\
& $1.02^{\#}$ & $0.06^{\#}$ & $0.89^{\#}$ & $0.07^{\#}$ \\
\hline
\end{tabular}

${ }^{\star} P<0.05$, compared with the control group; ${ }^{\#} p<0.05$, compared with TNF- $\alpha$ group. I + T, Icariin +TNF- $\alpha$; NF $+\mathrm{T}$, NF-kB inhibition +TNF- $\alpha$

\section{Effect of icariin on TNF- $\alpha-$ mediated chondrocyte apoptosis}

As shown in Figure 2 and Table 3, the mRNA and protein expressions of Bax in the cartilage tissues of rats in the TNF- $\alpha$ intervention group were significantly higher than those in the control group, but the mRNA and protein expressions of $\mathrm{Bcl}-2$ were significantly lower than those in the control group $(p<0.05)$. In contrast, the mRNA and protein expressions of Bax in the cartilage tissues of the icariin +TNF- $\alpha$ group and NF-kB 
inhibition +TNF-a group were significantly lower than those in the TNF- $\alpha$ intervention group, but the mRNA and protein expressions of $\mathrm{Bcl}-2$ were markedly higher than those in the TNF- $\alpha$ intervention group $(p<0.05)$.

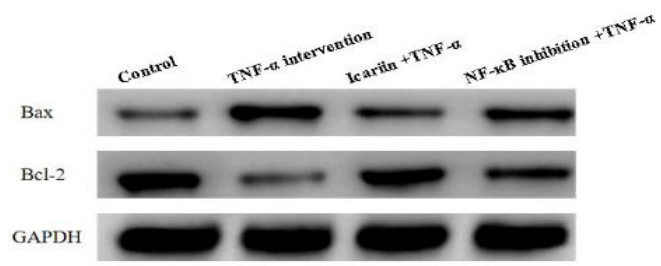

Figure 2: Effect of icariin on TNF- $\alpha$-mediated changes in chondrocyte $\mathrm{Bax}$ and $\mathrm{Bcl}-2$ proteins

Table 3: Effect of icariin on Bax and $\mathrm{Bcl}-2$ proteins in TNF- $\alpha$-treated chondrocytes (mean \pm SD, $n=8$ )

\begin{tabular}{lcccc}
\hline \multirow{2}{*}{ Group } & \multicolumn{2}{c}{ Bax } & \multicolumn{2}{c}{ Bcl-2 } \\
\cline { 2 - 5 } & mRNA & Protein & mRNA & Protein \\
\hline \multirow{2}{*}{ Control } & $1.00 \pm$ & $0.39 \pm$ & $1.00 \pm$ & $0.60 \pm$ \\
& 0.01 & 0.02 & 0.01 & 0.09 \\
TNF-a & $3.89 \pm$ & $0.71 \pm$ & $0.20 \pm$ & $0.32 \pm$ \\
& $1.02^{*}$ & $0.06^{*}$ & $0.03^{*}$ & $0.05^{*}$ \\
$\mathrm{I}+\mathrm{T}$ & $1.45 \pm$ & $0.45 \pm$ & $0.71 \pm$ & $0.50 \pm$ \\
& $0.08^{\#}$ & $0.05^{\#}$ & $0.08^{\#}$ & $0.07^{\#}$ \\
$\mathrm{NF}+\mathrm{T}$ & $2.66 \pm$ & $0.50 \pm$ & $0.48 \pm$ & $0.47 \pm$ \\
& $1.03^{\#}$ & $0.07^{\#}$ & $0.07^{\#}$ & $0.06^{\#}$ \\
\hline
\end{tabular}

${ }^{*} p<0.05$, compared with the control group; ${ }^{\#} p<0.05$, compared with TNF- $\alpha$ group. I + T, Icariin +TNF- $\alpha$; NF $+\mathrm{T}, \mathrm{NF}-\mathrm{kB}$ inhibition $+\mathrm{TNF}-\alpha$

\section{Effect of icariin on NF-KB signaling pathway}

The p-p65 protein level in the cartilage tissue of rats in the TNF- $\alpha$ intervention group was significantly higher than that in the control group, and the expression of NF-KB was significantly lower than that in the control group $(P<0.05)$. However, the p-p65 protein expressions levels in the cartilage tissue of the icarin +TNF- $\alpha$ group and NF-KB inhibition +TNF- $\alpha$ group were significantly lower than those in the TNF-a intervention group, and IKBa was significantly lower than that in the TNF- $\alpha$ intervention group $(p<0.05)$. These results are shown in Figure 3 and Table 4.

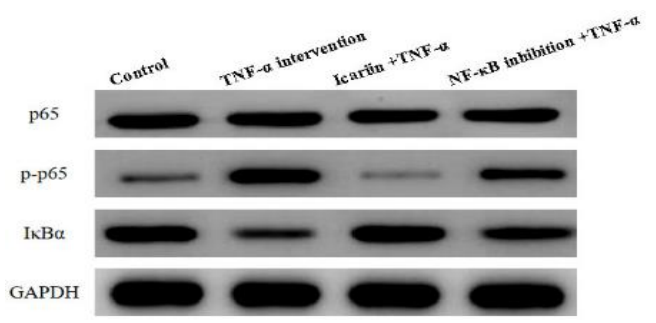

Figure 3: Effect of icariin on NF-KB signaling-related proteins
Table 4: Effect of icariin on NF-kB signaling-related proteins (mean $\pm \mathrm{SD}, \mathrm{n}=8$ )

\begin{tabular}{lcc}
\hline Group & $\begin{array}{c}\text { p65/p- } \\
\mathbf{p 6 5}\end{array}$ & IKBa \\
\hline Control & $0.39 \pm$ & $0.68 \pm 0.10$ \\
& 0.05 & \\
TNF- $\alpha$ & $0.82 \pm$ & $0.37 \pm 0.08^{*}$ \\
& $0.15^{\star}$ & \\
Icariin +TNF- $\alpha$ & $0.42 \pm$ & $0.70 \pm 0.12^{\#}$ \\
NF-kB inhibition & $0.09^{\#}$ & $0.56 \pm$ \\
+ TNF- $\alpha$ & $0.08^{\#}$ & $0.57 \pm 0.07^{\#}$ \\
\hline${ }^{*} P<0.05$, compared with the control group; ${ }^{\#} p<0.05$, \\
compared with TNF- $\alpha$ group
\end{tabular}

\section{DISCUSSION}

It is believed in Western medicine that osteoarthritis is a chronic inflammatory disease involving multiple mechanisms associated with cytokines and inflammatory mediators, leading to imbalance between normal degradation and synthesis of chondrocytes, subchondral bone and extracellular matrix [7]. In traditional Chinese medicine, osteoarthritis belongs to the category of "bone numbness and knee pain", and its pathogenesis is due to the response of the positive and deficient constitution to cold and dampness, phlegm and blood stasis. The symptoms of osteoarthritis are joint pain accompanied by the pathological characteristics of qi stagnation and blood stasis, deficiency of liver and kidney, and blocking of dampness and heat, resulting in incompatibility of qi and blood, and obstruction of meridians and collaterals [8].

Inflammatory cytokines are involved in the pathogenesis of cartilage degeneration and osteoarthritis. Cytokines such as IL-1 and TNF- $\alpha$ are important mediators of osteoarthritis. The cytokine TNF- $\alpha$ is secreted by macrophages, fibroblasts and chondrocytes. It increases the release of growth factors in synovial membrane, endothelial cells and fibroblasts, and enhances the formation of osteoarthritis pannus $[9,10]$. In addition, TNF- $\alpha$ stimulates chondrocytes to secrete fibrin lysosomal activator, and accelerates arthritis injury. It stimulates connective tissue cells and polymorphonuclear cells to produce small inflammatory mediators such as prostaglandins. At the same time, TNF- $\alpha$ upregulates the expressions of IL-1, IL-6 and IL12 , resulting in an inflammatory reaction cascade.

The NF-kB family is involved in a wide range of biological activities including cell differentiation, proliferation, autophagy and apoptosis, and plays an important role in most immune responses and inflammatory responses [11]. Several studies 
have now demonstrated the effect of NF-KB on chondrocytes. It is known that NF-kB and MAPK are ERK1/2 involved in the expression of type II collagen, leading to chondrocyte destruction and apoptosis $[12,13]$. Other scholars have found that TNF- $\alpha$ promotes the transformation of chondrocytes into mast cells by regulating NF-KB signaling pathway, and also damage the structure of articular cartilage [14].

Icariin is a natural substance extracted from Herba epimedii. It exerts a variety of pharmacological effects. Increasing attention has been paid to its therapeutic effects and associated mechanisms in the endocrine, nervous and cardiovascular systems. Modern studies of traditional Chinese medicine have found that icariin exerts powerful pharmacological effects which enhance the phagocytosis by macrophages and enhance the body's specific immunity [15-18]. Moreover, the pharmacological effect of icariin on the skeletal system is effective in the treatment of osteoporosis.

Recent studies have reported that icariin enhanced chondrocyte proliferation and chondrogenic differentiation of bone marrow mesenchymal stem cells, and reduced the destruction of articular cartilage [19]. The results of this study showed that the levels of IL-1, IL-6 and IL-12 in the cartilage tissues of rats in the TNF- $\alpha$ intervention group were significantly higher than those in the control group, and that intervention with icariin significantly inhibited the pro-inflammatory response of TNF- $\alpha$ and the overexpression of related factors, suggesting that icariin may inhibit chondromalacia by inhibiting inflammatory response of cells.

Further analysis showed that icariin significantly reduced the TNF-a-induced autophagy inhibition and the apoptosis induced by inflammatory factors. Therefore, it is not unreasonable to suggest that icariin may eliminate TNF- $\alpha$-induced autophagy inhibition and reduce apoptosis. In order to unravel its mechanism of action, it was demonstrated that $\mathrm{p}-\mathrm{p} 65$ protein levels in the cartilage tissues of icariin + TNF- $\alpha$ and NF-KB inhibition +TNF- $\alpha$ groups were significantly lower than that in the TNF- $\alpha$ intervention group.

\section{CONCLUSION}

This study has demonstrated that TNF- $\alpha$ promoted the production of a large number of inflammatory factors by chondrocytes through regulation of the NF-kB signaling pathway, inhibition of chondrocyte autophagy and enhancement of apoptosis. However, icariin inhibited the NF-k B signaling pathway, reduced the formation of TNF- $\alpha$ and inflammatory metabolites, activated autophagy, and inhibited apoptosis, thereby protecting the chondrocytes.

\section{DECLARATIONS}

\section{Conflict of interest}

No conflict of interest is associated with this work.

\section{Contribution of authors}

We declare that this work was done by the author(s) named in this article and all liabilities pertaining to claims relating to the content of this article will be borne by the authors. All authors read and approved the manuscript for publication. Yi Yu conceived and designed the study, Jun Xiong, Hui Zou, Yi Yu collected and analysed the data, while Jun Xiong wrote the manuscript. Jun Xiong and Hui Zou contributed equally to this work as co-first author.

\section{Open Access}

This is an Open Access article that uses a funding model which does not charge readers or their institutions for access and distributed under the terms of the Creative Commons Attribution License (http://creativecommons.org/licenses/by/ 4.0) and the Budapest Open Access Initiative (http://www.budapestopenaccessinitiative.org/rea d), which permit unrestricted use, distribution, and reproduction in any medium, provided the original work is properly credited.

\section{REFERENCES}

1. Pagenstert G, Knupp M, Valderrabano V, Hintermann B. Realignment Surgery for Valgus Ankle Osteoarthritis. Oper Orthop Traumatol 2018; 21(1): 425-432.

2. Yennan $P$, Suputtitada A. Effects of aquatic exercise and land-based exercise on postural sway in elderly with knee osteoarthritis. Asian Biomed 2010; 4(5): 739-745.

3. Zhou Z, Tian F, An N, Zhang Y, Wang C, Guo L. MiR-300 Serves as Potential Biomarker to Screen Knee Osteoarthritis Patients by Targeting TNFa. Clin Lab 2018; 64(4): 577-584

4. Vlachopoulos C, Gravos A, Georgiopoulos G, TerentesPrintzios $D$, loakeimidis $N$, Vassilopoulos $D$, Stamatelopoulos K, Tousoulis D. The effect of TNF-a antagonists on aortic stiffness and wave reflections: a meta-analysis. Clin Rheumatol 2018; 37(2): 515-526.

5. Deng $Y$, Chen LB. Experimental study of icariin promoting differentiation of bone marrow mesenchymal

Trop J Pharm Res, September 2020; 19(9): 1855 
stem cells into osteoblasts by activating Notch signaling pathway. Acta Herbala Sinica 2017; 1(12): 2393-2398.

6. World Health Organization. Principles of laboratory animal care. WHO Chron 1985; 39: 51-56.

7. Kawaguchi H. International and National Guidelines of Osteoarthritis Treatment. Analytical Chem 2017; 34(12): 1-9.

8. Han H. Advances in the prevention and treatment of osteoarthritis with active components of traditional Chinese medicine. J China Pharm Univ 2018; 49(3): 279-285.

9. Kocijancic D, Leschner S, Felgner S, Komoll RM, Frahm M, Pawar V, Weiss $S$. Therapeutic benefit of, Salmonella, attributed to LPS and TNF- $\alpha$ is exhaustible and dictated by tumor susceptibility. Oncotarget 2017; 8(22): 36492-36508.

10. Mashhadizadeh S, Farbood Y, Dianat M, Khodadadi A, Sarkaki A. Therapeutic effects of ellagic acid on memory, hippocampus electrophysiology deficits, and elevated TNF- $\alpha$ level in brain due to experimental traumatic brain injury. Iran J Basic Med Sci 2017; 20(4): 399-407.

11. Huang $P$, Tsai $K$, Chen $Y$, Lin $H T$, Hung $C H$. Exercise Combined with Ultrasound Attenuates Neuropathic Pain in Rats Associated With Downregulation of IL-6 and TNF- $\alpha$, but With Upregulation of IL-10. Anesthesia Analgesia 2017; 124(6): 2038-2044.

12. Bortolotto V, Grilli M. Novel insights into the role of NF-KB p50 in astrocyte-mediated fate specification of adult neural progenitor cells. Neural Regen Res 2017; 12(3): 354-357.
13. Toth $R$. The PP4R1 sub-unit of protein phosphatase PP4 is essential for inhibition of NF-KB by merkel polyomavirus small tumour antigen. Oncotarget 2017; 8(15): 25418-25432.

14. Egan SM, Karasik E, Ellis L, Gollnick SO. miR-30e* is overexpressed in prostate cancer and promotes NF-KBmediated proliferation and tumor growth. Oncotarget 2017; 8(40): 67626-67638.

15. Chen XF, Yu L, Xia Q. Experimental study on osteogenic differentiation of pre-osteoblasts Mc3t3-e1 induced by icariin. Chin J Integr Tradit Chin Western Med 2018; 38(6): 687-692.

16. Yang L, Shi $H X$, Lin $P$, Xue HY, Wang YG, Liu XF. Research on Vitro Anti-Oxidant and Anti-Cancer Activity of Cynomorium Songaricum Rupr.'S Extracts. Acta Med Mediterr 2018; 34(1): 13-19.

17. Zhu Q, Ma JD, Dong X, Zhang L. The Protective Effect of The Combination of Xiaoxianxiong Decoction and Guizhi Fuling Pills on Rat Vascular Endothelium PostMyocardial Infarction. Acta Med Mediterr 2018; 34(3): 765-771.

18. Lin WL, Lu XF, Xu GF, Wei ZH. Study on The Royal Physical Therapy and Medical Treatment of Lumbar Intervertebral Disc Protrusion in Middle Aged and Elderly Patients. Acta Med Mediterr 2019; 35(1): 93-101.

19. San JW, Wei ZY, Li GY, Gao YQ, Wang JX, Wang XN. Molecular mechanism of icariin in the treatment of tdp43 - mediated chondrocytosis in osteoarthritis. J Exp Surg 2018; 35(10): 1986-1986. 